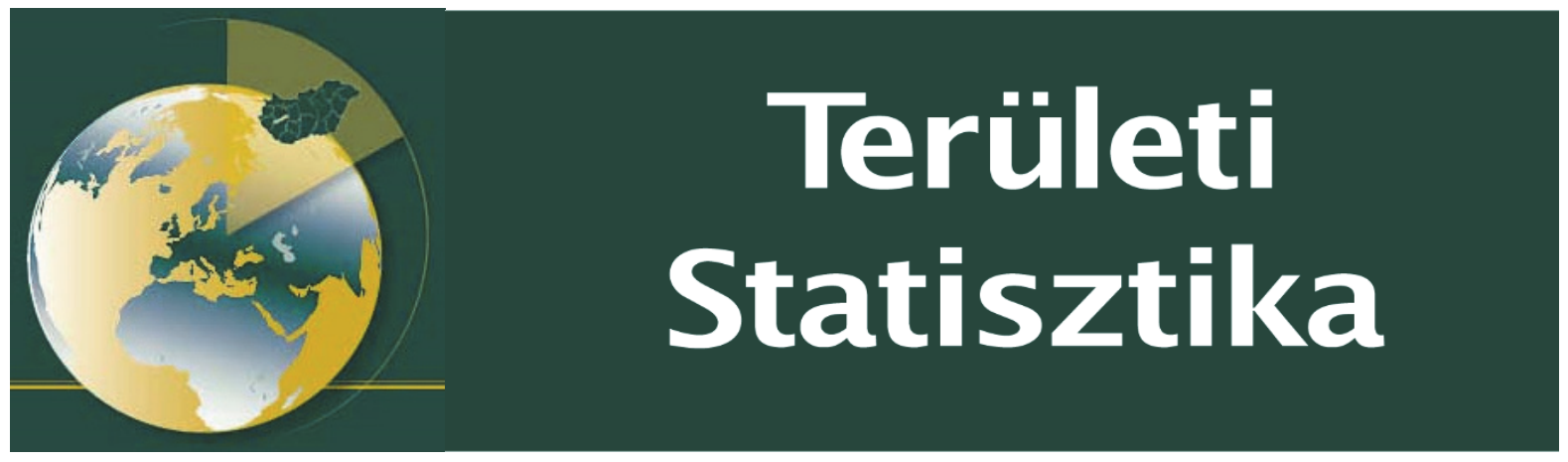

Közzététel: 2020. szeptember 21.

A tanulmány címe:

A turizmusbiztonság társadalmi és gazdasági összefüggéseinek statisztikai vizsgálata

Szerzők:

Mátyás Szabolcs-Németh József-Ritecz György

https://doi.org/10.15196/TS600503

Az alábbi feltételek érvényesek minden, a Központi Statisztikai Hivatal (a továbbiakban: KSH) Területi Statisztika c. folyóiratában (a továbbiakban: Folyóirat) megjelenó tanulmányra. Felhasználó a tanulmány, vagy annak részei felhasználásával egyidejüleg tudomásul veszi a jelen dokumentumban foglalt felhasználási feltételeket, és azokat magára nézve kötelezönek fogadja el. Tudomásul veszi, hogy a jelen feltételek megszegéséböl eredö valamennyi kárért felelösséggel tartozik.

1) A jogszabályi tartalom kivételével a tanulmányok a szerzői jogról szóló 1999. évi LXXVI. törvény (Szjt.) szerint szerzői műnek minősülnek. A szerzői jog jogosultja a KSH.

2) A KSH földrajzi és időbeli korlátozás nélküli, nem kizárólagos, nem átadható, térítésmentes felhasználási jogot biztosít a Felhasználó részére a tanulmány vonatkozásában.

3) A felhasználási jog keretében a Felhasználó jogosult a tanulmány:

a) oktatási és kutatási célú felhasználására (nyilvánosságra hozatalára és továbbítására a

4. pontban foglalt kivétellel) a Folyóirat és a szerző(k) feltüntetésével;

b) tartalmáról összefoglaló készítésére az írott és az elektronikus médiában a Folyóirat

és a szerző(k) feltüntetésével;

c) részletének idézésére - az átvevő mú jellege és célja által indokolt terjedelemben és az eredetihez híven - a forrás, valamint az ott megjelölt szerző(k) megnevezésével.

4) A Felhasználó nem jogosult a tanulmány továbbértékesítésére, haszonszerzési célú felhasználására. Ez a korlátozás nem érinti a tanulmány felhasználásával előállított, de az Szjt. szerint önálló szerzői műnek minősülő mű ilyen célú felhasználását.

5) A tanulmány átdolgozása, újra publikálása tilos.

6) A 3. a)-c.) pontban foglaltak alapján a Folyóiratot és a szerző(ke)t az alábbiak szerint kell feltüntetni:

„Forrás: Területi Statisztika c. folyóirat 60. évfolyam 5. számában megjelent, Mátyás Szabolcs-Németh József-Ritecz György által irt, A turizmusbiz̨tonság társadalmi és gazdasági összefüggéseinek statisztikai vizsgálata c. tanulmány”

7) A Folyóiratban megjelenő tanulmányok kutatói véleményeket tükröznek, amelyek nem esnek szükségképpen egybe a KSH, vagy a szerzők által képviselt intézmények hivatalos álláspontjával. 


\section{A turizmusbiztonság társadalmi és gazdasági összefüggéseinek statisztikai vizsgálata}

\section{Statistical analysis of the social and economic contexts of tourism safety}

Mátyás, Szabolcs

Nemzeti Közszolgálati Egyetem E-mail: matyas.szabolcs@uni-nke.hu

Németh, József nemethjozsefnk@gmail.com

Ritecz, György

Nemzeti Közszolgálati Egyetem E-mail: riteczgy@gmail.com

Kulcsszavak: turizmus, turizmusbiztonság, bűnözés, migráció, rendészet

Keywords: tourism, tourism security, crime, migration, law enforcement
A tanulmány a turizmus egy hazánkban kevésbé kutatott területét, a turizmusbiztonságot vizsgálja. A szerzők azokra a társadalmi és gazdasági összefüggésekre világítanak rá, amelyek befolyásolják a turizmus volumenét és hatással vannak a turizmusbiztonságra. A tanulmány a továbbiakban a hazánkba érkező külföldi turistákra fókuszálva azt vizsgálja, hogy 2009 és 2018 között milyen mennyiségi és minőségi változások jellemezték a bűnelkövetôket és a sértetteket. A sértettek esetében a szerzők főként arra a kérdésre keresnek választ, hogy a külföldi turisták számának növekedése milyen hatással volt a külföldi sértettek számának alakulására.

The study examines a less researched area of tourism in Hungary, tourism safety. The authors shed light on the social and economic contexts that influence the volume of tourism and have an impact on tourism security. In the following, the study examines the quantitative and qualitative changes that characterized criminals and victims between 2009 and 2018, focusing on foreign tourists arriving in Hungary. In the case of victims, the authors mainly seek answers to the question of how the increase in the number of foreign tourists has affected the change in the number of foreign victims.

Beküldve: 2020. június 11.

Elfogadva: 2020. július 6. 


\section{Bevezetés}

A mobilitás az emberek, az élőlények egyik alapvető tevékenysége, sőt létfenntartásuk egyik elengedhetetlen módja. Lényegét tekintve a turizmus is a mobilitás egyik formája. Globalizálódó világunkban megváltoztak a volumenek és a trendek, ezért érdemes ezeket részletesebben elemezni (Kincses 2012, 2019).

A XX. század végi, illetve a harmadik évezred első évtizedeinek eseményei új megvilágításba helyezték a biztonság és a mobilitás fogalomkörét, főleg Európában. ${ }^{1)}$ A mobilitás meghatározása szinte evidens, így az értelmező szótárak szúkszavúan csak annyit említenek: mozgó, elmozdítható, illetve könnyen mozgó (személy) (Eőry 2007).

A biztonság meghatározása már bonyolultabbnak túnik. Mindenesetre a (köz-) biztonsághoz való jog állampolgári jogként definiálható (Gönczöl 1999). Ez azért is indokolt, mivel a biztonság az emberi lét egyik alapszükséglete. Ennek része a közbiztonság, amelynek megléte nélkül a normális élet elképzelhetetlen, ezért is fogalmazza meg az Emberi Jogok Egyetemes Nyilatkozatának (1993 évi XXXI. tv) 5. cikkelye, hogy „mindenkinek joga van a szabadságra és a személyi biztonságra ...”.

A biztonságot fenyegetô veszélyek - ezek fajtái, intenzitásuk, erősségük - térben és időben jelentős mértékben változnak, nem különben ezek szubjektiválódott érzetei. Az e veszélyek elhárításában részt vevő intézmények, módszerek, eljárások, intézkedések kiválasztását a mindenkori konkrét helyzethez kell igazítani, a komplexitás szem előtt tartásával.

\section{A biztonság és turizmusbiztonság' összefüggései}

„A biztonság alapvető egyéni, nemzeti és közösségi(szövetségi) érték, olyan állapot, vagy helyzet, amely a fenyegetések és a veszélyek tudatosan (hallgatólagosan) elfogadott, elviselt szintjén valósul meg. Alapját a külső fenyegetettségtől való megbízható védelem, a (védendő, vagy védelmi) rendszer belső stabilitása, rendezettsége képezi. A biztonság nem lehet állami, vagy hatósági monopólium, hanem 'immateriális társadalmi (össz)termék', amely érdekközelítés útján, egyeztetett cselekvés, tudatos kooperáció útján jön létre" (biztonság /1/ megközelítés - Beregnyei 2008, 75. old.). „A XXI. században a biztonság mérésének leggyakoribb kifejezése az emberek szubjektív biztonságérzete ${ }^{3)}$. A biztonságérzet növelése garantálja a szubjektív biz-

1) Az elmúlt néhány évtized jelentős biztonsági kockázatot jelentő eseményei közül említsük meg - többek között - a 2000-es évek első évtizedében induló migrációs hullámot, az Európa számos országát érintő terrorhullámot, az újfajta hadviselési módokat (lásd Kelet-Ukrajna, Krím-félsziget), az egyre jelentősebbé váló éghajlatváltozást.

2) Széles körben, mindenki által elfogadott meghatározása a turizmusbiztonságnak nincs. A témával foglalkozó kutatók viszont abban egyetértenek, hogy a turizmusbiztonság egy komplex fogalom, aminek számos összetevője van, melyek a közbiztonság, a közlekedésbiztonság, a természeti környezet biztonsága, az egészségbiztonság, a mûszaki biztonság, a fogyasztás biztonsága és az eligazodás/tájékozódás biztonsága.

3) „Szubjektív biztonságérzet: adott egyén személyes biztonságérzete, amely jelentősen befolyásolja az emberi magatartást és viselkedést” (Boda 2020, 544. old.).

Területi Statisztika, 2020, 60(5): 567-580; DOI: 10.15196/TS600503 
tonság megteremtését és ezzel együtt a közbiztonság fokozását is. Ebben a megközelítésben a biztonság középpontjában maga az ember áll. A biztonság az ő szemszögéből kerül megitélésre, azon szempontok alapján, hogy a lakókörnyezetében, munkahelyén, utazásai közben milyen biztonságra veszélyes cselekményekkel ... találkozik, vagy milyen cselekményekről hall” (Balla 2013, 23. old.). Hogyan is kapcsolódik a mobilitás és a biztonság egymáshoz, valamint a turizmushoz? Ehhez az ember pszichéjéhez, a jól ismert maslow-i szükségletpiramist kell végiggondolnunk. Maslow szükséglethierarchiája szerint, a szükségletek a társadalmi-lakossági igények mindazon termékek, szolgáltatások és tevékenységek iránt, amelyek a társadalmiemberi lét fenntartásához, a társadalomban élő egyén létezéséhez szükségesek. A szükséglet hiányérzet, amely motiválja a hiányérzet megszüntetésére irányuló tudatos törekvést, és szándékolt cselekvést vált ki. Vagyis „minden tett és állapot 'eredője' a szükségletek" (Maslow 1943, 370. old.). Ezt tovább gondolva, Argyris szerint az élet értelme az egyén szükségleteinek kielégítése, s közben mindig új szükségletek teremnek, de a létfenntartás szükséglete (melynek része a biztonság) örök (Sutermeister 1966). Ebből következik, hogy a mobilitás - a szükséglet felől megközelítve - tehát nem más, mint az ember mozgása a térben annak érdekében, hogy szükségletei minél nagyobb mértékben kielégíthetôk legyenek.

Érdemes végiggondolnunk azt is, hogy a turizmus azon túl, hogy kellemes időtöltés, egyfajta értelemben az ismeretlen (az addig számunkra új, nem vagy nem eléggé ismert dolgok) megismerésének lehetősége. Mivel félelmeink alapja leggyakrabban az ismeretlen, azaz a megismerés, az ismeretlen „terének szúkítése” (így a turizmus is) a szubjektív biztonság növelésének egyik módja, vagyis maga a turizmus biztonságerősítő tényező is lehet (Bódis-Michalkó 2017, Molnár-Remenyik 2019).

A turizmusbiztonság kérdéskörével kapcsolatban megemlítendő, hogy míg a téma nemzetközi szakirodalma rendkívül széles körü, addig a hazai források korlátozottak. Néhány évvel ezelőtt ennek enyhítésére a turisztikai és rendészeti szakemberek életre hívták a „Turizmus és Biztonság Nemzetközi Konferenciát”, melyet eddig négy alkalommal rendeztek meg, a konferenciához pedig konferenciakötetek is készültek. A turizmusbiztonság témakörében elókészületben lévő egyetemi jegyzet hozzájárulhat a témakörben meglévő szakirodalmi hiány pótlásához (Mátyás 2020).

A mobilitást az idő dimenzióján vizsgálva alapvetően két részre bonthatjuk. Egyrészt a rövid távú mobilitás, melynek egyik legszembetúnőbb példája maga a turizmus.

Az 1963-ban, Rómábann) megrendezett ENSZ-konferencia meghatározásai alapján:

- Látogató minden olyan személy, aki bármely célból, kivéve a kereső foglalkozást, állandó lakóhelyén kívül más országba utazik.

4) 1963-ban az ENSZ Gazdasági és Szociális Tanácsa által szervezett római idegenforgalmi konferencia statisztikai megközelítésű meghatározást fogadott el.

Területi Statisztika, 2020, 60(5): 567-580; DOI: 10.15196/TS600503 
- Turista olyan időszakos látogató, aki legalább 24 órát tölt a meglátogatott országban, miközben utazásának célja kapcsolatban állhat szabadidős tevékenységekkel, családdal, vallással, egészséggel, üzlettel, hivatással stb.5)

- Kiránduló szintén időszakos látogató, azonban 24 óránál kevesebbet tartózkodik a felkeresett helyen (Nagy 1963a, b, Marton 1963, Kovács-Takács 1966, Lengyel 2004).

Másrészt, a hosszú távú mobilitás nem más, mint a migráció, de erre most nem térünk ki (lásd bővebben: Ritecz 2017).

1. ábra

A turizmus és a migráció trendjének alakulása

Changing trends in tourism and migration

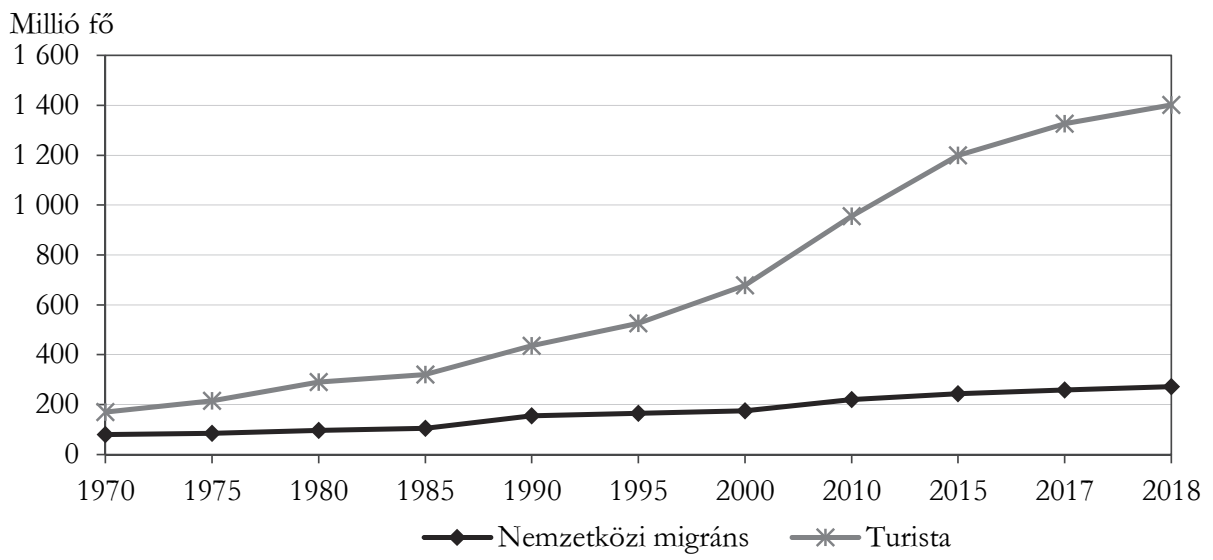

Forrás: ENSZ (2019), UNWTO (2019).

A mobilitás két fó ága (1. ábra) 1970-tôl szinte töretlenül növekedett, de míg a turizmus ez idő alatt nyolcszorosára, addig a hosszabb távú mobilitás, vagyis a migráció „,csak” a három és félszeresére nőtt.

Mind a migráció, mind a turizmus ilyen arányú növekedése alapvetően a globalizációra vezethető vissza (lásd bővebben: Ritecz-Sallai 2016). Az emberek ezáltal lehetőséget kaptak arra, hogy közelebbi és távolabbi vidékeket, embereket, kultúrákat, gazdasági és társadalmi berendezkedéseket ismerjenek meg. Kezdetben a média útján, majd akár személyes kapcsolataikkal, illetve az információs forradalom lehetőségeivel a felgyorsult - szinte online - információáramlást kihasználva nemcsak tájékozódhattak, de akár döntési helyzetbe is kerülhettek (Mátyás et al. 2019). E döntési pozíció abból is eredeztethető, hogy a múlt évszázad végén az országok jelentôs részének egymáshoz való viszonya is jelentôsen megváltozott, felbomlottak a gyarmatbirodalmak, önálló (nem mindig nemzet-) államok jöttek létre, illetve a

5) Jelen tanulmányban turizmusként ezt a meghatározást vesszük alapul, tekintettel arra is, hogy a nemzetközi statisztikák is ezt alkalmazzák.

Területi Statisztika, 2020, 60(5): 567-580; DOI: 10.15196/TS600503 
másik kiemelendő változás, hogy megszűnt az ún. szocialista világrendszer. Ezentúl az infotechnika robbanásszerű fejlődése is nagyságrendbeli mobilitási fejlődést kínált nemcsak a közúti és a vasúti fejlődésben, hanem főleg a légiközlekedés fejlődésében, jelentős mértékben a fapados járatok árzuhanásábólo) eredően. Mind emellett szükség volt arra is, hogy - a világ gazdasági potenciáljának emelkedésével7) - az emberek egyre nagyobb részének az életminősége változzék, vagyis anyagi lehetőségeik legyenek utazásra, lakóhelyük megváltoztatására. A társadalmi változások viszont nemegyszer nemzetiségi, vagy országok közötti konfliktusokká váltak, illetve nemritkán diktatórikus rendszerek alakultak ki, melyek ún. toló faktorként jelentkeztek (lásd bővebben: Teke 2006, Ritecz-Sallai 2016).

Az elmúlt évtizedben bekövetkezett változások az emberek többségének szemléletét, világlátását is megváltoztatta/változtatja, mely azt is maga után vonja, hogy egyre többen érzik úgy, hogy a szükségleteik legalább egy részét - rövid vagy hosszú távon - legteljesebben így elégíthetik ki. Ebbe beletartozik a háborútól, a leégett házából menekülő vándor is, de a másik vetület is, amikor valaki a fizikai és/vagy szellemi egészségének megőrzése végett rekreációs pihenésre megy egy másik városba, vagy akár egy másik országba (Lados-Hegedús 2017, 2019).

A gazdasági és társadalmi szerkezetváltozás következtében míg fokozatosan csökken a mezőgazdaság, majd az ipar gazdasági és a munkaerő-hasznosítási szerepe, addig a szolgáltatások jelentősége egyre növekszik. A globalizáció intenzitásának emelkedésével a szolgáltatásokon belül (is) a turizmusnak - a legtöbb országban egyre nagyobb a GDP-n belüli aránya, és a foglalkoztatottaknak is egyre nagyobb hányada kötődik ehhez a szektorhoz. A turizmusbiztonság mérhetővé tétele, illetve a tendenciák kimutatása érdekében, talán legcélszerűbb a nemzetközi összevetést is tartalmazó Világ versenyképességi jelentés (Global Competitiveness Report GCR $)^{8)}$ tanulmányozása. Ez a jelentés rendszeresen és részletesen értékeli egyes országok (általában 130-150 ország) gazdasági, társadalmi viszonyait a versenyképesség szempontjából. E jelentés részadataiból állitják össze a Turisztikai és utazási versenyképességi jelentést (Travel \& Tourism Competitiveness Report - TTC).9) A GCR és a TTC indikátoraiból, illetve az elemzett adataiból alapvetően két terület

6) Az ezredforduló előtt még a földrészen belüli repülőjegy ára is a havi átlagfizetés 2-4-szerese volt, míg 2019-ben a havi átlagfizetés tizedéből már lehet repülőjegyet venni.

7) 1980 és 2019 között a világon az országok egy főre jutó bruttó hazai terméke (gross domestic product GDP) átlagosan 4,4-szeresére emelkedett (worldometers.info/gdp).

8) A Világgazdasági Fórum (World Economy Forum - WEF) globális versenyképességről szóló jelentés a szerző fordítása (https://www.weforum.org).

9) A WEF 13 éve minden évben megjelenteti az országokra vonatkozó turisztikai versenyképességi indexét a TTC-jelentésben. Az index 4-6 nagy témát, altémákba sorolva 10-18 indikátort értékel (sajnos ezek köre évente eltérhet egymástól), amelyek a „Támogató környezeti tényezők” között a biztonság a 2., az egészség és higiénia a 3. tényező (Sziva-Michalkó 2018).

Területi Statisztika, 2020, 60(5): 567-580; DOI: 10.15196/TS600503 
kapcsolható direkt módon a turizmusbiztonsághoz: az egészségügy és a biztonság ${ }^{10)}$. Ezek közül jelen tanulmány az utóbbival foglalkozik.

A biztonság szerepe az elmúlt egy-másfél évtizedben felértékelődött, ennek ellenére a turizmus területét érintő hazai kutatások elvétve foglalkoznak csak a turisták sértetté és elkövetôvé válásával, holott egy úti cél kiválasztásánál napjainkban alapvető szemponttá vált a biztonság (Birkner et al. 2018, Mészáros et al. 2019). A turizmusbiztonság hét alappillére (közbiztonság, egészségbiztonság, fogyasztás biztonsága, természeti környezet biztonsága, műszaki biztonság, közlekedés biztonság, eligazodás/tájékozódás biztonsága) közül a legfontosabb a közbiztonság (BujdosóRemenyik 2008, Dávid et al. 2008, Mansfeld-Pizam 2006). Jelen kutatás is elsősorban a közbiztonság területét érinti, úgy az elkövető, mint a sértett oldaláról.

\section{A turisták elkövetövé válása}

\section{Nehézségek és módszertani problémák az elkövetők vizsgálata során}

Az elmúlt néhány évtized főbb turisztikai mutatószámai azt mutatják, hogy egyaránt jelenősen emelkedett a turizmusban részt vevők száma és a turizmusból származó bevétel. Jelenleg a Föld lakosságának közel 20\%-a vesz részt a turizmus valamely formájában (2018-ban: 1,4 milliárd fö), és e szektorban globálisan több mint 1700 milliárd dolláros bevétel keletkezett (UNWTO 2019). A növekedés azonban olyan problémákat is felvet, amelyekkel - véleményünk szerint - a hazai és a külföldi kutatások nem minden esetben annak mértéke szerint foglalkoznak.

Egyik ilyen terület a turisták által elkövetett jogsértés, amelyrôl az országok szintjén nem áll rendelkezésre semmilyen egységes statisztikai adat, holott a turisták által elkövetett bűncselekmények száma a több milliót is elérheti. Természetesen a bűnözés mellett számos egyéb olyan terület is van, amely az iparszerú méreteket öltô turizmussal összefüggő problémaként jelentkezik, azonban keveset foglalkoznak vele a hazai kutatók (például környezetvédelem). ${ }^{11}$

Mint már említettük, nincs olyan statisztikai nyilvántartás, amely globálisan mutatná be a turisták által elkövetett jogsértéseket. Számos esetben a hazai adatbázisok sem rendelkeznek egyértelmú kriminálstatisztikai adatokkal, holott ez létkérdés lenne, hiszen csak akkor lehet felismerni a legújabb trendeket, ha megfelelő adatok birtokában vagyunk (Hautzinger 2019). A terület fontosságát jelzi, hogy hazánk

\footnotetext{
10) Jelen tanulmány írásakor a hazai és a globális mobilitásra, turizmusra egyaránt jelentős mértékben rányomta bélyegét a COVID-19 járvány. Ezen tanulmány kereteibe nem fért bele e hatás elemzése, de a tudományos igényesség és objektivitás is megköveteli a szubjektív elemek kiküszöbölését, ezért kutatócsoportunk foglalkozik az adatgyűjtéssel és -feldolgozással. Az eredmények közzététele egy későbbi tanulmány tárgyát képezi.

11) A téma iránti nemzetközi érdeklődést mutatja, hogy a turizmus és környezetszennyezés témakörében már évtizedekkel ezelőtt is számos tanulmány látott napvilágot. Például Weiss et al.(1998), Kovacs-Innes (1990).
}

Területi Statisztika, 2020, 60(5): 567-580; DOI: 10.15196/TS600503 
esetében a turizmus napjainkra a legfontosabb szektorok közé került, amit egyaránt bizonyít a foglalkoztatottak száma és a turizmusból származó bevétel nagysága ${ }^{12}$.

Az Országos Rendőr-főkkapitányság (ORFK) adatbázisa alapján kimutatható a turisták egyes csoportjainak elkövetővé válása, mivel több, a turistákra vonatkozó kategória is létezik, azonban nem különböztethető meg, hogy az elkövető turista hazai vagy külföldi állampolgár volt-e. A Belügyminisztérium által üzemeltetett, nyiltt hozzáférésú Búnügyi Statisztikai Rendszer adatbázis (https://bsr-sp.bm.hu) adatai ugyancsak nem tartalmaznak az elkövetők állampolgárságára vonatkozó adatokat, kizárólag csak „magyar” vagy „külföldi” kategóriát.

\section{A bưnelkövető turisták mennyiségi mutatói}

Az alfejezethez szükséges a regisztrált bűnelkövető és a tranzitutazó fogalmának magyarázata. A kriminálstatisztikában korábban az „ismertté vált bűnelkövető” fogalmát használták, 2009-tôl viszont a „regisztrált bűnelkövető”-t, amely megfelel a nemzetközi gyakorlatnak és pontosabban kifejezi azt, hogy kizárólag a hatóság által ismertté vált (a hatóság által regisztrált) bűnelkövetőket tartalmazza (Borbíró et al. 2016). A tranzitutazó nem a klasszikus értelemben vett turista, csupán azért utazik át egy országon (jelen esetben Magyarországon), hogy elérje úti célját (Kincses et al. 2014, 2016a, b). Döntő többségük az autópályákon közlekedik, a benzinkutaknál étkezik, tankol, esetleg ott tölti az éjszakát is (nemritkán a gépkocsiban, kamionban).

A turisták elenyésző hányada válik regisztrált bűnelkövetôvé. Az ORFK adatbázisában szereplő „turista” kategória kevesebb mint 1\%-át (2017-ben: 0,34\%), míg a „turisztikai szállóvendég” kategória az elkövetők statisztikailag elhanyagolható hányadát adják. A tranzitutazók ugyancsak turistának számítanak ${ }^{13}$, és hazánk esetében ők teszik ki a turisták legnagyobb hányadát. Többségükben Nyugat-Európán dolgozó román, török, szerb és bolgár vendégmunkások, akik hazánkon keresztül, gépjárművel mennek haza, illetve utaznak vissza. Esetükben ugyancsak nem kiugró a bűncselekmények száma. Megállapítható, hogy a regisztrált esetszámok a 2011. évi 823-ról folyamatosan csökkennek, és 2017-ben mindössze 4 bűncselekményt követtek el tranzitutazók. Az általuk elkövetett bűncselekmények többségében olyan típusú jogsértések, melyek a lakosság szubjektív biztonságérzetét kevésbé rontják, ugyanis többségében az autópályákhoz és a határátkelőhelyekhez kötődnek.

A hazai statisztikai rendszer több kategóriát is elkülönít, amelyek a turisták (magyar és külföldi egyaránt) által elkövetett jogsértéseket tartalmazzák. Ilyen kategória a turista, a turisztikai szállóvendég és a tranzitutazó. Ezeken kívül számos további kategória is létezik, amely a külföldi állampolgárok jogsértéseit összesíti. Ezeket jelen

12) „A KSH szatellit számla adatai szerint a turizmus gazdasághoz való közvetlen hozzájárulása a GDP 6,8\%-a, a közvetett hatásokat is magába foglaló hozzájárulás pedig a GDP 10,7\%-a. A turisztikai ágazatokban betöltött állások száma 428 ezer fö, a munkahelyek 10,0\%-át a turizmus generálta közvetlenül, a közvetlen és közvetett hatásokat összesítve pedig a nemzetgazdasági foglalkoztatottság 13,2\%-át adja a turizmus.” (https://mtu.gov.hu)

13) A köznyelvi és nem a korábban ismertetett UNWTO-fogalomrendszer szerint.

Területi Statisztika, 2020, 60(5): 567-580; DOI: 10.15196/TS600503 
kutatás nem vizsgálja, mivel ezen elkövetők nem turistaként tartózkodtak az országban, például a jogellenesen ott tartózkodó; letelepedés céljából; menekült státust kérö; menekült státusú, menedékes; tartózkodási engedéllyel egyéb célból; tartózkodási engedéllyel munkavégzés céljából és tartózkodási engedéllyel tanulmányok folytatása céljából kategóriákat. Ezek a kategóriák kis esetszámúak és a jogellenesen ott tartózkoodó kategóriába tartozók relatíve nagy esetszáma emeli csak meg az egyéb külföldi kategóriát. A hazánkban jogellenesen tartózkodók 2017. évi (80) és 2018. évi (36) esetszáma töredéke az ezt megelőző évekének. Ugyancsak nem veszi figyelembe a kutatás az „utazó bűnöző” kategóriát, amelybe bár egyes években kétezernél több elkövető tartozott, azonban közöttük nemcsak külföldiek, hanem magyar állampolgárok is lehetnek, amely ezáltal ugyancsak tévútra viheti a kutatást. Megemlítendő, hogy turisztikai értelemben az utazó búnelkövetők is számos esetben kvázi turistának tekinthetők, hiszen előfordul, hogy valahol legalább 24 órát és/vagy vendégéjszakát is eltöltenek (1. táblázat).

1. táblázat

A (rendőrség által regisztrált) turista bűnelkövetők főbb statisztikai mutatói Main statistical indicators of tourist offenders (registered by the police)

\begin{tabular}{|c|c|c|c|c|c|c|c|c|c|}
\hline Mutató & 2009 & 2010 & 2011 & 2012 & 2013 & 2014 & 2015 & 2016 & 2017 \\
\hline $\begin{array}{l}\text { Regisztrált bűn- } \\
\text { cselekmény, darab }\end{array}$ & 394034 & 447186 & 451371 & 472225 & 377829 & 329575 & 280113 & 290779 & 226452 \\
\hline $\begin{array}{l}\text { Regisztrált bűn- } \\
\text { elkövetô, fő }\end{array}$ & 111714 & 122528 & 112894 & 108305 & 109797 & 108474 & 101492 & 100933 & 92896 \\
\hline Turista, fö & 434 & 489 & 422 & 409 & 483 & 692 & 377 & 308 & 319 \\
\hline $\begin{array}{l}\text { Turisztikai szálló- } \\
\text { vendég, fó }\end{array}$ & 89 & 62 & 58 & 39 & 51 & 32 & 34 & 55 & 53 \\
\hline Utazó bűnöző, fő & 2320 & 2267 & 1749 & 1256 & 943 & 85 & 25 & 13 & 15 \\
\hline Tranzitutazó, fő & 833 & 681 & 823 & 748 & 636 & 491 & 50 & 18 & 4 \\
\hline $\begin{array}{l}\text { Egyéb külföldia), } \\
\text { fó }\end{array}$ & 1205 & 1153 & 1377 & 1792 & 1020 & 516 & 1270 & 2755 & 94 \\
\hline
\end{tabular}

a) Egyéb külföldi az Egységes nyomozó hatósági és ügyészségi bűnügyi statisztika (ENyÜBS) szerint a következő kategóriákat tartalmazza: jogellenesen ott tartózkodó; letelepedés céljából; menekültstátust kérő; menekültstátusú, menedékes; tartózkodási engedéllyel egyéb célból; tartózkodási engedéllyel munkavégzés céljából; tartózkodási engedéllyel tanulmányok folytatása céljából.

Forrás: ORFK, KSH és Bűnügyi Statisztikai Rendszer.

\section{A turisták sértetté válása}

\section{A látenciát előidéző legfontosabb tényezők}

A sértettek kutatásával a széles körű szakirodalommal rendelkező áldozattan (viktimológia) foglalkozik. A turizmusban részt vevők sértetté válása viszont meglehetősen kevés kutatás tárgya, holott globálisan, éves szinten több tíz millióra tehetjük a sértettek számát. Korábbi szakirodalmi forrásokra hivatkozva kijelenthetjük, hogy igen magas a látencia a turisták sérelmére elkövetett bűncselekmények esetében (Mátyás 2016, Michalkó 1996). A látencia mértékét számos tényező növeli és befo- 
lyásolja, így többek között az időfaktor (az egyre rövidülő utazások csak súlyos búncselekmény elkövetése esetén teszik lehetővé /érdemessé/ a feljelentést megtételét), a nyelvtudás nem megfelelő szintje (a hatóság és a sértett részéről egyaránt), a turista sérelmére elkövetett jogsértés tárgyi súlya és típusa (rendszerint csak nagyobb tárgyi súlyú bűncselekmény esetén tesznek feljelentést, illetve olyan ügyben, ami nem okoz a későbbiekben kellemetlenséget a feljelentő családja és környezete előtt), a nemzetek közötti eltérő feljelentési hajlandóság (lásd bővebben: Mátyás 2020).

\section{Sértettek és föbb büncselekménytípusok}

Mint korábban említettük, a látencia egyik legfóbb oka az, hogy a turisták a kis tárgyi súlyú cselekmények esetén csak kisebb arányban tesznek feljelentést. Ezek rendszerint olyan vagyon elleni búncselekmények, ahol a cselekménnyel okozott kár/sérelem nem jelentős vagy nem áll arányban a feltételezhetően ráfordított idővel (például egy kétnapos utazás során nem éri meg fél napot eltölteni egy feljelentés megtételével, ha például az okozott kár csak 10000 forint). A feljelentett cselekmények elsősorban olyan jogsértések, amelyek súlyos orvosi ellátást igényelnek, meghiúsítja a hazautazást (például úti okmányok eltủnése, gépjármúben okozott kár) stb.

A külföldi turisták esetében számos olyan tényező sorolható fel, amelyek hozzájárulnak áldozattá válásukhoz. Egyik legfóbb tényező a nyelvtudás hiánya, mivel nem tudják magukat „megvédeni”, a saját jogaikat érdemben képviselni. A turisták sok esetben a könnyelműségükkel is hozzájárulnak ahhoz, hogy áldozattá váljanak, mivel kevésbé körültekintőek, jobban „elengedik” magukat, magukkal szemben megengedőbbek annál, mintha otthon tartózkodnának. Különösen a nyugat-európai és az észak-amerikai turisták esetében figyelhető az meg, hogy jelentős értéket képviselő múszaki berendezésekkel rendelkeznek (például kamera, telefon), amely ugyancsak felkelti a bűnelkövetôk érdeklődését, továbbá kevésbé vannak felkészülve az utcán elkövetett bűncselekmények megelőzésére és kivédésére.

A turisták sérelmére elkövetett bűncselekmények közül a leggyakoribbak a különféle lopások (például zseblopás, strandlopás, szállodai lopás, autófeltörés, iratlopás és a különféle trükkös lopások). Elsősorban a fiatalabb, az éjszakai életet megismerni vágyó korosztály válhat rablás vagy kifosztás áldozatává. Esetükben legtöbbször az alkohol vagy a kábítószer is közrejátszik mint oksági tényező. A testi sértéseket ugyancsak a fiatalabb korosztály tagjai szenvedik el, ugyanis számos esetben a szórakozóhelyeken kialakult konfliktusok eszkalálódnak testi sértéssé vagy garázdasággá.

A turisták relatíve gyakran válnak különféle csalások áldozatává, azonban a látenciát már csak az a tény is növeli, hogy sok esetben a turista nem is szerez arról tudomást, hogy megkárosították (például taxival történő utazások során) (Madai 2010, 2011). A fogyasztás biztonságához tartozik, amikor a vásárló (turista) nem azt a minőségú terméket kapja, amit ő megvásárolni kívánt, ezért joggal érezheti magát

Területi Statisztika, 2020, 60(5): 567-580; DOI: 10.15196/TS600503 
becsapva (ezzel az elkövetők a „rossz minőségű termék forgalomba hozatala” és a „versenytárs utánzása” tényállásokat valósítják meg).

A nem szándékosan elkövetett cselekményekhez sorolhatók többségében a közlekedési balesetek, melyeknek a turisták is részeseivé válhatnak. Súlyosabb esetben, közlekedési bűncselekmény bekövetkeztekor, rendszerint a hatóság tudomására is jut a cselekmény. A nem gyakori sértetté válás eseteihez sorolhatók a különféle bankkártyákkal elkövetett jogsértések, illetve a terrorcselekményekhez sorolható cselekmények (lásd bővebben: Mátyás 2020, Ritecz 2018).

\section{A sértetté vált turisták száma}

A sértettek vizsgálata során lehetőség adódik a természetes személyek és a jogi személyek vizsgálatára. Tanulmányunkban a sértettek döntő többségét kitevő külföldi természetes személyeket vizsgáljuk. A sértettek között a statisztikai rendszer megkülönböztet továbbá „ismert” és „,ismeretlen” természetes személyt. Kutatásunk tárgyát kizárólag az ismert, külföldi sértettek képezik. A hazai statisztikai rendszer (és a legtöbb külföldi rendszer) hiányossága, hogy a sértettről nem lehet azt megállapítani, hogy külföldi állampolgárként milyen minőségben tartózkodott hazánkban. E kategóriában szerepel ugyanis a több vendégéjszakát hazánkban eltöltő turista, az országon keresztül utazó vendégmunkás (tranzitturista), a hazánkban tanuló külföldi diák és a menekültstátust kérố menekült is. Mindezek alapján nem állapítható meg egzakt módon az egyes alkategóriák kategórián belüli aránya. Valószínűsíteni viszont többnyire lehet, például a sértettek állampolgársági összetétele és/vagy életkora alapján, továbbá aszerint, hogy egy adott ország állampolgára milyen minőségben tartózkodhatott az országban. A rövid módszertani kitérőnk után, a hazánkban sértetté vált külföldi állampolgárokról az ügyforgalmi statisztika adatai (2. táblázat) alapján megállapíthatjuk:

- A regisztrált természetes személy sértettek száma 2012 és 2017 között folyamatosan, közel 50\%-kal csökkent (272 431-ről 139254 főre).

- A regisztrált külföldi természetes személy sértettek számában hasonló kedvező fordulat következett be, 36,5\%-os csökkenés (8698-ról 5524 főre).

- A külföldi sértettek aránya az összes sértettből 2-4\% körül ingadozik, a sértettek számának csökkenése ellenére is valamelyest nôtt az arányuk a vizsgált időszakban. Ez turizmusbiztonsági relevancia szempontjából egyrészt azzal magyarázható, hogy a hazai sértettek aránya nagyobb ütemben csökkent, másrészt pedig 2012 és 2017 között a turistaérkezések száma több mint 5 millió fővel nőtt (10,3-ről 15,7 millió főre). A 2017. évi mutató alaposabb vizsgálatából egyértelmúen arra következtethetünk, hogy a turistaérkezés jelentős mértékú növekedése nem tette lehetővé a külföldi sértettek számának nagyobb mértékú csökkenését. Az elért eredményekhez pedig - véleményünk szerint - a rendvédelmi szervek erőfeszítései is hozzájárultak. 
A külföldi sértettek főbb statisztikai mutatói

2. táblázat

Main statistical indicators of foreign victims

\begin{tabular}{l|r|r|r|r|r|r|r|r|r}
\hline \multicolumn{1}{c|}{ Mutató } & 2009 & 2010 & 2011 & 2012 & 2013 & 2014 & 2015 & 2016 & 2017 \\
\hline $\begin{array}{l}\text { Regisztrált termé- } \\
\text { szetes személy } \\
\text { sértett, fó } \\
\begin{array}{l}\text { Regisztrált külföl- } \\
\text { di természetes } \\
\text { személy sértett, fö }\end{array}\end{array}$ & 211420 & 245677 & 259277 & 272431 & 245667 & 214537 & 183402 & 156753 & 139254 \\
$\begin{array}{l}\text { A sértettekből a } \\
\text { külföldi sértettek } \\
\text { aránya, \% }\end{array}$ & 7770 & 7947 & 8698 & 7699 & 6397 & 6127 & 5704 & 5524 \\
$\begin{array}{l}\text { Regisztrált bún- } \\
\text { cselekmény, darab }\end{array}$ & 2,4 & 3,16 & 3,07 & 3,19 & 3,13 & 2,98 & 3,34 & 3,64 & 3,97 \\
$\begin{array}{l}\text { Turistaérkezések } \\
\text { száma, millió fó }\end{array}$ & 9,0 & 9,5 & 10,2 & 10,3 & 10,6 & 12,1 & 14,3 & 15,2 & 15,7
\end{tabular}

Forrás: ORFK, Bűnügyi Statisztikai Rendszer, UNWTO.

A turistaérkezések számának jelentős növekedése kapcsán mindenképpen érdemes azt kiemelni, hogy bár a kevesebbet költő turisták vannak többségben, az elmúlt évek trendjei alapján egyre növekszik a távolabbi országokból (főként Ázsia országaiból) hazánkba látogató turisták száma. Ők azok, akik több vendégéjszakát töltenek el, nagyobbak a náluk lévő értékek, ezért a turizmusbiztonság szempontjából kiemelten fontos az, hogy minél kevesebb sértett legyen, hiszen ezek a turisták potenciálisan nagyobb célpontot jelentnek a bűnelkövetőknek. Ha pedig őket valamilyen sérelem éri, akkor nagyobb eséllyel tesznek feljelentést, már csak az őket ért kár nagysága miatt is.

\section{Összegzés}

A tanulmány első fejezetében a mobilitást, a biztonság és a turizmus viszonyát vizsgáltuk. Kijelenthetjük, hogy a mobilitás az alapvető tevékenységek közé sorolható, így a turizmus is egyfajta mobilitási tevékenység. Számos társadalmi és gazdasági okkal magyarázható, hogy az elmúlt évtizedekben globálisan jelentősen nőtt a turisták száma. Ezzel párhuzamosan azonban emelkedett a turisták között a sértettek és az elkövetôk száma is. Éves szinten több millió turista válik sértetté és bűnelkövetővé, azonban ez többnyire nem jelenik meg elkülönítve a kriminálstatisztikai adatsorokban. Rávilágítottunk arra, hogy hazánkban sem megfelelő a külföldi sértettek és elkövetôk statisztikai elkülönítése. Világtrendként figyelhető meg, hogy az elmúlt évtizedben csökkent a bűncselekmények száma, ezzel párhuzamosan pedig a külföldi sértettek és elkövetők száma is. Az esetszámok csökkenése ellenére is azonban egy adott úti cél egyik legfőbb vonzereje az lehet, ha kedvezőek a kriminálstatisztikai

Területi Statisztika, 2020, 60(5): 567-580; DOI: 10.15196/TS600503 
adatai. Számos nemzetközi és hazai felmérés is bizonyította, hogy a célország választásakor - különösen családok esetében - a biztonság az egyik legfőbb tényező, ami gyakran már az úti cél reklámozása során is megjelenik, így napjainkban a turizmusbiztonság jelentős felértékelődésének lehetünk tanúi.

\section{IRODALOM}

BALLA, J. (2013): A biometrikus adatokat tartalmazó úti és sqemélyazonositó okmányok biatonságnöveló hatása a határ-és köz̧biztonság alakulására Doktori (PhD) értekezés, Nemzeti Közszolgálati Egyetem, Budapest.

BEREGNYEI, J. (szerk.) (2008): Rendészettudományi szószedet MRTT, Budapest.

Birkner, Z.-MARTON, Zs.-Keller, K. (2018): Az innováció értelmezése a turizmusbiztonság területén - különös tekintettel az oktatás és a kutatás területére Rendốrségi Tanulmányok 1 (3): 71-80.

BODA, J. (főszerk.) (2020): Rendészettudományi Szaklexikon Dialóg Campus, Budapest.

BÓDIS, G.-MichALKÓ, G. (2017): Jöttünk, láttunk, visszatérünk: a visszatérő turisztikai forgalom Területi Statisztika 57 (3): 295-310. https://doi.org/10.15196/TS570303

Borbíró, A.-GÖNCZÖL, K.-KEREZSI, K.-LÉVAY, M. (2016): Kriminológia Wolters Kluwer, Budapest.

BujDOSÓ, Z.-REMENYIK, B. (2008): A hazai turisták életminőségének a feltérképezése az Észak-Magyarország Régióban. In: DÁvID, L. (szerk.): A turizmus szerepe az Észak-Magyarország Régióban I-II. pp. 40-48., Károly Róbert Főiskola, Gyöngyös.

DÁvid, L.-Bujdosó, Z.-TóTH, G. (2008): Tourism planning in the Hajdú-Bihar - Bihor Euroregion. In: SÜLI-ZAKAR, I. (szerk.): Neighbours and partners: on the two sides of the border pp. 323-332., Kossuth Egyetemi Kiadó, Debrecen.

ENSZ (2019): World Migration Report 2020 International Organization for Migration, Geneva.

EŐRY, V. (szerk.) (2007): Értelmęó szótár Tinta Könyvkiadó, Budapest.

GÖNCZÖL, K. (1999): A közbiztonsághoz való jog az emberi jogok körében Kriminológiai és kriminalisztikai tanulmányok 36: 10-22.

HAuTZINGER, Z. (2019): Külföldiekkel szembeni büntetőeljárás? Miskolci Jogi Sz̨emle 14 (2. különszám) 1. kötet: 349-358.

KINCSES, Á. (2012): A Kárpát-medence ezredforduló utáni migrációs hálózatának vizsgálata Központi Statisztikai Hivatal, Budapest.

KINCSES, Á. (2019): A Magyarországon élő külföldi kötődésű népesség területi jellegzetességei, 2011-2017 Területi Statisztika 59 (5): 463-497. https://doi.org/10.15196/TS59050

KINCSES, Á.-MichalKó, G.-TÓTH, G. (2014): A Magyarország átutazó forgalmában érintett települések lehatárolása Területi Statisz̧tika 54 (3): 237-252.

KInCSES, Á.-TÓTH, G.-TÖMÖRI, M.-MiCHALKÓ, G. (2016a): Az átutazó turizmus magyarországi sajátosságai, különös tekintettel a költésre Területi Statisz̨tika 56 (4): 455-476. https://doi.org/10.15196/TS560406

Kincses, Á.-Tóth, G.-TÖMÖRI, M.-Michalkó, G. (2016b): Identifying settlements involved in Hungary's transit traffic Regional Statistics 6 (1): 193-216. https://doi.org/10.15196/RS06110

Területi Statisztika, 2020, 60(5): 567-580; DOI: 10.15196/TS600503 
Kovacs, K.-InNES, S. (1990): The impact of tourism on Harp Seals in the Gulf of Saint Lawrence Canada Applied Animal Bahavior Science 26: 15-26.

KOVÁCS, L.-TAKÁCS, J. (1966): Az idegenforgalom alakulása és fejlódése Magyarorsqágon 1945-1965. Panoráma, Budapest.

LADOS, G.-HEGEDỨs, G. (2017): A visszavándorlás és az identitásváltozás kapcsolatának vizsgálata a hazatérő magyarok példáján Területi Statiştika 57 (5): 512-536. https://doi.org/10.15196/TS570503

LAdos, G.-HeGEDÜs, G. (2019): Return migration and identity change: A Hungarian case study Regional Statistics 9 (1): 150-167. https://doi.org/10.15196/RS090109

Lengyel, M. (2004): A turizmus általános elmélete Heller Farkas Gazdasági és Turisztikai Szolgáltatások Főiskolája, Budapest.

MADAI, S. (2010): Gondolatok a csalás néhány kriminológiai aspektusáról Collectio Iuridica Universitatis Debreceniensis 8: 161-179.

MADAI, S. (2011): A csalás büntetőjogi értékelése HVG ORAC, Budapest.

Mansfeld, J.-PIZAm, A. (ed.) (2006): Tourism, Security and Safety from theory to practice Taylor and Francis Group, London-New York.

MARTON, J. (1963): A római világkongresszus tanulságai Idegenforgalom 1963. október.

Maslow, A. (1943): A theory of human motivation Psychological Review 50 (4): 370-396. https://doi.org/10.1037/h0054346

MÁTYÁs, SZ. (2016): A külföldi bűnelkövetők területi és strukturális jellemzői Magyarországon. In: HAUTZINGER, Z. (szerk.): A migráció bünügyi hatásai pp. 75-88., MRTT, Budapest.

MÁTYÁs, SZ. (2020): A turisták sérelmére elkövetett jogsértések (megjelenés alatt).

MÁTYÁs, Sz.-SALlai, J.-TihanYI, M.-VÁRI, V. (2019): A rendőri elérhetőség és a bűnözés közötti összefüggések térbeli elemzése Területi Statisðtika 59 (2): 152-163. https://doi.org/10.15196/TS590202

MÉSZÁros, B.-JobBÁGY, Z.-HutKAI, Zs.-KIS, N. (2019): Biztonság és bizalom a kormányzatban. In: KAISER, T. (szerk.): A Jó Állam mérhetösége III. pp. 9-29., Dialóg Campus Kiadó, Budapest.

Michalkó, G. (1996): A nemzetközi turizmus bűnözésföldrajzi aspektusai Budapesten Belïgyi Szemle 34 (11): 12-30.

MOLNÁR, Cs.-REMENYIK, B. (2019): A megasportesemények turisztikai hatásai Magyarországon Területi Statisz̧tika 59 (3): 300-327. https://doi.org/10.15196/TS590303

NAGY, L. (1963a): A római Idegenforgalmi Konferencia előtt Idegenforgalom 1963. augusztus.

NAGY, L. (1963b): A római Idegenforgalmi Konferencia után Idegenforgalom 1963. november.

RiteCZ, GY. (2017): Migráció a XXI. század kędetén Globe Edit, Saarbrücken.

RiTECZ, GY. (2018): Nemzetközi mobilitás és a turizmus hatásai Határrendészeti Tanulmányok 15 (4): $25-57$.

Ritecz, Gy.-SAllai, J. (2016): A migráció trendjei, okeai és kezelésének lehetöségei 2.0. Hanns Seidel Alapítvány, Budaörs.

Sutermeister, R. A. (1966): Ember és termelékenység Közgazdasági és Jogi Könyvkiadó, Budapest.

SzIVA, I.-MiCHALKÓ, G. (2018): A biztonság szerepe a desz̨tinációs versenyképességben (kézirat).

TEKE, A. (2006): A „,pull-push factor” biztonság alapú megközelítése. In: Magyarországot érintó nemretkëzi migráció MK Katonai Biztonsági Hivatal, Budapest.

Területi Statisztika, 2020, 60(5): 567-580; DOI: 10.15196/TS600503 
Weiss, O.-Norden, G.-Hilscher, P.-VAnReusel, B. (1998): Ski tourism and environmental problems: Ecological Awareness among Different Groups International Review for the Sociology of Sport 1998 (4): 367-379.

\section{INTERNETES FORRÁSOK}

https://www.weforum.org/reports/how-to-end-a-decade-of-lost-productivity-growth (letöltve: 2019. december 2.)

https://bsr.bm.hu/ (letöltve: 2020. március 11.)

UNWTO (2019): International Tourism Highlights 2019 edition

(https://www.e-unwto.org/doi/pdf/10.18111/9789284421152 - letöltve: 2020. május 15.)

worldometers.info/gdp (letöltve: 2019. december 25.)

\section{JOGSZABÁLY}

1993 évi XXXI. tv.: Az emberi jogok és alapvető szabadságok védelméről szóló Rómában 1950. novemberében kelt Egyezmény 